\title{
Intraspecific differentiation by exterior in horses of different breeds
}

\author{
Vladimir Demin ${ }^{1, *}$, Timur Tarchokov ${ }^{2}$,Elena Ryabova ${ }^{1}$, Inna Tsyganok ${ }^{1}$, and Natalia \\ Kulmakova ${ }^{1}$ \\ ${ }^{1}$ Federal State Budgetary Educational Institution of Higher Vocational Education Russian State \\ Agrarian University - Moscow Timiryazev Agricultural Academy 49 Timiryazevskaya str, 127550 \\ Moscow, Russia \\ ${ }^{2}$ Kabardino-Balkarian State Agricultural University named after V. M. Kokov, Lenin Avenue, 1V, \\ 360030 Nalchik, Russia
}

\begin{abstract}
The analysis of the exterior features of horses of the roadster and heavy draft horse breeds by basic and supplementary measurements of body articles and conformation indexes was carried out in order to study the intraspecific differentiation. The results showed significant differences between the racing roadster breeds and heavy draft breeds. The racing roadster breeds were similar in most respects, but the Russian Saddle Horse had more differences compared to other roadster breeds. Soviet Heavy Draft mares were reliably superior to riding mares in most measurements and conformation indices, but inferior to them in terms of neck length. Our research has shown that the selection of highly specialized types of horses leads to a distinct differentiation between breeds of horses in the exterior structure. The resulting digital data should be used for the development of standards and regulations in the breeding of horses for different uses.
\end{abstract}

\section{Introduction}

The large number of horse breeds is due to the great variety of uses for them. As far back as antiquity, different horse types began to appear associated with the predominant use of horses in harness in chariots or for horseback riding. The treatises of the time described the selection of a horse suitable for particular tasks.

As the horse breeding and hippology developed, the science of exterior design, which became a separate discipline in the 18th century, underwent various formative stages, but at the same time included completely opposite views and currents that could be completely opposite: the search for the "ideal exterior" based on golden proportions or the proportions of famous horses.

The 19th century saw the intensification of agriculture and the emergence of highly specialized breeds of animals, including horses. New breeds and types of horses, while

\footnotetext{
${ }^{*}$ Corresponding author: demin@,rgau-msha.ru
} 
having high performance in certain areas, differ dramatically in size, physique, and points. The attempt to generalize the characteristics of different breeds and to describe ideal forms in connection with the specialization of breeds instead of finding just the ideal conformation was made in the 19th century, but the effort to reduce the variety of breeds to a few ideal types has been criticized and found to be untenable [13].

The next stage in the development of the doctrine of external conformation was the trend towards the exterior functionality, in which the unity of form and function is inextricably linked. For each type and use specific exterior requirements need to be developed. Nowadays, the breed shaping process in horse breeding continues, and breeds and types of horses that meet modern requirements are created and recreated. A large proportion of the combined use breeds - riding draft and working draft - which were previously used in agriculture and the army, have been reoriented towards sporting use and have acquired (transformed into) a riding horse type. There has been an increase in the specialization of horse breeds according to the use, so that the Russian Saddle breed has not just been re-bred as a sporting horse, but primarily as a horse for one type of equestrian sport - dressage [3, 13].

The specific requirements in the different uses of the horses lead to changes in the exterior and physique of the horses and reinforce the intra-breed differentiation in terms of exterior. In horses of different breeds, the biomechanics of movement, performance and other attributes are largely determined by conformation. This is characteristic of both cultured breeds and local horses [1, 2, 4, 5, 7-11, 14-18]. For example, a study of the measurements of the exterior of thoroughbred horses showed a mutual influence of both measurements and joint angles on each other. The use of linear measurements and angulation values will, according to the researchers, reveal the correctness of limb structure and performance potential of thoroughbred horses. This will contribute to the choice of horse for the sport with less risk of lameness [11]. In Iranian Turkoman horses, a medium to high heritability of measurements was found, which suggests the possibility of breeding for these traits [5]. Detailed measurements of horse skull have shown that more information is available with geometric morphometry compared to linear morphometry [12]. Measurements of joint angles, such as the hip joint, are an aid in preventing lameness in the horse, as it has been proven that there is a relationship between the angle of the hip joint and ligament damage [14]. It has been found that the treading and walking speed in Icelandic horses were most was the most influenced by height at the withers, height at hips, trunk length and forelimb length $(p<0.05)$ [16]. A gene influence on the angular size of certain joints in Lippiciana and Franche-Montagne horses was found. To improve the assessment of horse exterior features, scientists have investigated the use of a spatial model of the horse shape. Significant relationships $(\mathrm{p}<0.05)$ with withers height, shoulder length and inclination, leg structure, stride length at a trot were found $[6,7]$. A comparison of the aboriginal (primitive) horse breeds - Konik and Hutsul, based on 25 measurements and 24 body indices, showed that, despite the fact that both breeds are similar, Konyk and Hutsul horses have different measurement ratios. The authors attribute the differences between Hutsul and Konik horses to the breeding of Hutsul horses in the highlands. Konik horses were also compared and Polish half-bred and thoroughbred horses. It has been revealed that half-bred and thoroughbred breeds clearly differ in their exterior structure from Tarpan-like horses. The specific structure of the exterior of aboriginal Tuvinian horses makes it relatively easy to identify them visually. Conformation studies, as the authors point out, are important for establishing the characteristics of different horse populations [8-10].

Thus, in order to intensify the breeding work with the various horse breeds, it is necessary to have a clear and precise understanding of the requirements for exteriors and how these can be characterized in numerical terms. 


\section{Materials and Methods}

The aim of our work is to study the exterior traits in horses of different breeds.

Objectives

1. Comparison of the basic and supplementary measurements of heavy draft and riding horses.

2. Analysis of primary and secondary conformation indexes in horses of different breeds.

The study is based on data on basic and additional measurements of Russian Saddle Horse mares of Starozhilov stud farm - 86 animals, 17 animals of Hanoverian breed of Elitar breeding farm, 13 animals of Budenny breed of Velikoknyazhessk stud farm, 54 animals of Soviet Heavy Draft breed of Perevozsk stud farm. The mares were measured between 2017 and 2020.

Four main and 18 additional body article measurements were taken, from which 31 conformation indexes were calculated.

The results were processed by conventional methods of statistical analysis

\section{Results and Discussion}

The selection of horses to increase height in different breeds occurs for different reasons. Horses used in classical equestrian sports tend to be higher at withers, because larger horses can jump over high obstacles more easily in show jumping and triathlon, and a larger horse looks better in dressage, which can give the judges some advantage when judging; with heavy draft breeds, a larger height is associated with greater live weight and therefore greater pulling power.

The mares of the studied breeds were very tall, with the largest of them being the Soviet Heavy Draft breed. Their average height at withers was $166.8 \mathrm{~cm}$, which is reliably higher than the average height of the Russian Saddle breed at $165.3 \mathrm{~cm}$. The average height at withers between mares of sporting riding breeds was not found to be a significant difference. As can be seen from Table 1, Soviet Heavy Draft mares were reliably superior to other mares in terms of basic measurements (with the exception of withers height compared to Budenny and Hanoverian mares). They differed considerably from riding mares in terms of physique, as shown by the indices calculated from the basic measurements: Soviet Heavy Draft mares had a more elongated body (by 7.5-9\%), a higher value of chest girth index (by 15-16\%), compactness (by 6\%) and bone structure (by 2-3\%) than riding horses; which had a format index close to $100 \%$ (square format), a lighter physique and less boniness.

Table 1. Basic measurements and body indices of producing mares of different breeds.

\begin{tabular}{|c|c|c|c|c|c|c|c|c|c|}
\hline \multirow[b]{2}{*}{ Breed } & \multirow[b]{2}{*}{$\frac{2}{2}$} & \multicolumn{4}{|c|}{ Body measurements (cm) } & \multicolumn{4}{|c|}{ Conformation indexes (\%) } \\
\hline & & 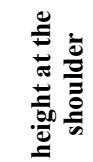 & ثี & 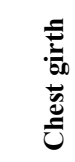 & 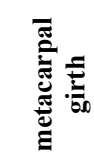 & 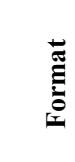 & 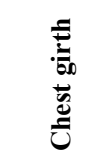 & 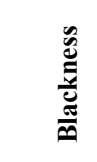 & 竞 \\
\hline $\begin{array}{l}\text { Russian Saddle } \\
\text { Horse }\end{array}$ & 86 & $\begin{array}{l}165.3 \\
\pm 0.34\end{array}$ & $\begin{array}{l}166.0 \\
\pm 0.49\end{array}$ & $\begin{array}{l}194.9 \\
\pm 0.68\end{array}$ & $\begin{array}{l}20.2 \\
\pm 0.07\end{array}$ & 100.4 & 117.91 & 117.41 & 12.22 \\
\hline Budyonny & 13 & $\begin{array}{l}165.3 \\
\pm 1.3 \\
\end{array}$ & $\begin{array}{l}167.1 \\
\pm 1.6 \\
\end{array}$ & $\begin{array}{l}196.2 \\
\pm 2.0\end{array}$ & $\begin{array}{l}21.0 \\
\pm 0.4 \\
\end{array}$ & 101.1 & 118.69 & 117.41 & 12.70 \\
\hline Hanoverian & 17 & $\begin{array}{r}166.2 \\
\pm 0.78 \\
\end{array}$ & $\begin{array}{r}169.2 \\
\pm 1.48 \\
\end{array}$ & $\begin{array}{r}197.5 \\
\pm 2.41 \\
\end{array}$ & $\begin{array}{l}21.7 \\
\pm 0.21 \\
\end{array}$ & 101.8 & 118.83 & 116.72 & 13.06 \\
\hline $\begin{array}{l}\text { Soviet Heavy } \\
\text { Draft }\end{array}$ & 54 & $\begin{array}{l}166.8 \\
\pm 0.51 \\
\end{array}$ & $\begin{array}{l}182.3 \\
\pm 1.0\end{array}$ & $\begin{array}{l}224.2 \\
\pm 1.7\end{array}$ & $\begin{array}{l}25.5 \\
\pm 0.1\end{array}$ & 109.3 & 134.4 & 122.98 & 15.3 \\
\hline
\end{tabular}


On the average values of the main measurements between riding mares, there was no significant difference, except for the metacarpal girth, in which the Hanoverian mare was superior to the Russian Saddle mare (21.7 and $20.2 \mathrm{~cm}$ respectively). Overall the Hanoverian mares were somewhat larger than Budenny and Russian Saddle mares. Russian Saddle mares have a square format (100.4\%), less massiveness and boniness compared with representatives of other sporting breeds; chest girth index reached $117.91 \%$ and metacarpus girth index was $12.22 \%$.

The different breeds of riding horses differ not only in the physique, but also in the size of individual body articles. When describing the exterior of heavy draft horses, it is common to mention the large head. In our research, the average length of the heads of the Soviet Heavy Draft mares was greater than that of the representatives of riding breeds $65.9 \mathrm{~cm}$, but the reliability of the difference between the averages established only with Russian Saddle mares, being the smallest in the head length $-60.52 \mathrm{~cm}$.

Russian Saddle breed mares have significantly shorter length of the head, as compared to Budenny and Hanoverian horses $(60.52,64.5$ and $64.3 \mathrm{~cm}$, respectively). This is indicated by the lower values of the big head index, which was $2-3 \%$ lower in Russian Saddle mares than in mares of other breeds. The ratio of the length of the head to the length of the body for Russian Saddle mares is also smaller than for Hanoverian and Budenny mares, which again shows that Russian Saddle horses are characterized by a small head. This is largely due to the fact that, in recreating the Russian Saddle breed, great care was taken to preserve the distinctive type of riding horse characteristic of the Orlov-Rostopchin horse (13). A small value of the ratio of head length to body length in Soviet Heavy Draft mares is due to their long body.

The length of the neck is important to the biomechanics of movement, as the neck and head act as a lever to change the position of the horse's centre of gravity, helping to change direction and pace. The long neck makes it easier to control the horse, especially during under-saddle work. Riding breed horses in our study had a neck length reliably $10 \mathrm{~cm}$ longer than the mares of the Soviet Heavy Draft breed. This is also evidenced by the larger ratio of neck length to withers height and body length in riding horses. Riding breed mares had no significant differences in neck length. However, the ratio of neck length to head length in Russian Saddle mares was the highest - 152.84\%, which gives the impression of a very long neck, while the ratio of neck length to head length in Soviet Heavy Draft mares was lower $-120.49 \%$, which emphasizes the short neck and makes the head visually larger.

Table 2. Measurements and indices that characterize the size of the head and neck in mares of different breeds.

\begin{tabular}{|c|c|c|c|c|c|c|c|c|c|c|}
\hline \multirow[b]{2}{*}{ Breed } & \multirow[b]{2}{*}{ i } & \multicolumn{4}{|c|}{ Body measurements (cm) } & \multicolumn{5}{|c|}{ Conformation indexes (\%) } \\
\hline & & 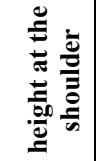 & 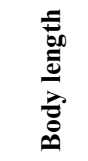 & 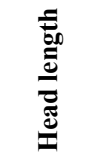 & 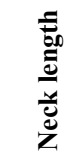 & 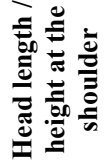 & 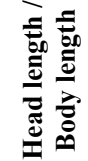 & 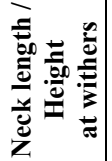 & 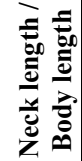 & 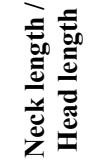 \\
\hline $\begin{array}{l}\text { Russian } \\
\text { Saddle } \\
\text { Horse }\end{array}$ & 86 & $\begin{array}{l}165.3 \\
\pm 0.34\end{array}$ & $\begin{array}{l}166.0 \\
\pm 0.49\end{array}$ & $\begin{array}{l}60.52 \\
\pm 0.27\end{array}$ & $\begin{array}{c}92.5 \\
\pm 1.04\end{array}$ & 36.61 & 36.46 & 55.96 & 55.72 & 152.84 \\
\hline Budyonny & 13 & $\begin{array}{c}165.3 \\
\pm 1.3\end{array}$ & $\begin{array}{c}167.1 \\
\pm 1.6\end{array}$ & $\begin{array}{c}64.5 \\
\pm 1.12\end{array}$ & $\begin{array}{r}93.3 \\
\pm 1.22 \\
\end{array}$ & 39.02 & 38.6 & 56.44 & 55.83 & 144.65 \\
\hline Hanoverian & 17 & $\begin{array}{l}166.2 \\
\pm 0.78 \\
\end{array}$ & $\begin{array}{r}169.2 \\
\pm 1.48 \\
\end{array}$ & $\begin{array}{r}64.3 \\
\pm 0.6 \\
\end{array}$ & \begin{tabular}{|c|}
91.2 \\
\pm 0.71 \\
\end{tabular} & 38.69 & 38.0 & 54.87 & 53.90 & 141.83 \\
\hline $\begin{array}{l}\text { Soviet } \\
\text { Heavy Draft }\end{array}$ & 54 & $\begin{array}{l}166.8 \\
\pm 0.51\end{array}$ & $\begin{array}{c}182.3 \\
\pm 1.0\end{array}$ & $\begin{array}{l}65.9 \\
\pm 0.6\end{array}$ & $\begin{array}{c}79.4 \\
\pm 1.01\end{array}$ & 39.51 & 36.15 & 47.6 & 43.55 & 120.49 \\
\hline
\end{tabular}

The following table shows the average height at withers, back and hip and the indices that describe the topline of sport mares and Soviet Heavy Draft mares. Soviet Heavy Draft 
is not only superior to other breeds mares in height at the withers, but at the height at back and hip (significantly in comparison with the Russian Saddle mares).

Horses of sport riding breeds had greater height at withers than at hip, and heavy draft mares had a slight modification - their height at hip was slightly higher than the height at withers. The traditional view is that modification is not desirable for riding horses, as it increases the load on the forelegs, but modification is not a serious disadvantage for heavy draft horses working under saddle, so it is not a serious exterior disadvantage. The topline curve can be characterized by the ratio of height at withers and hip to height at the back. as can be seen from Table 3, in Soviet Heavy Draft horses compared to riding mares, this curve was more pronounced because of the greater height at hips.

Among the groups of horses examined, the highest withers were of the Russian Saddle breed, with a difference of more than $10 \mathrm{~cm}$ between the withers height and the back height, as evidenced by the size of the ratio between these measurements. The ratio of height at withers and hip to height at back shows the curve of the topline and indicates that the curve was more pronounced in Russian Saddle mares than in Hanoverian and Budenny mares. Russian Saddle mares had a lower hip height than other horses. In Budenny mares height at hip was approaching the height at withers, which is quite acceptable for the breed, used mainly in show jumping, but not desirable for dressage horses.

Table 3. Measurements and indices that characterize the topline in mares of different breeds.

\begin{tabular}{|c|c|c|c|c|c|c|c|}
\hline \multirow[b]{2}{*}{ Breed } & \multirow[b]{2}{*}{ है } & \multicolumn{3}{|c|}{ Body measurements $(\mathrm{cm})$} & \multicolumn{3}{|c|}{ Conformation indexes (\%) } \\
\hline & & 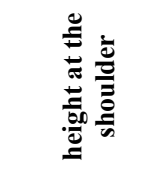 & 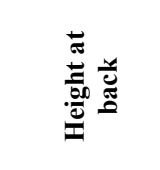 & 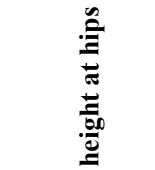 & : & 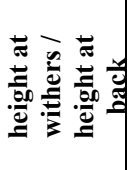 & 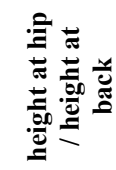 \\
\hline $\begin{array}{l}\text { Russian Saddle } \\
\text { Horse }\end{array}$ & 86 & $165.3 \pm 0.34$ & $154.94 \pm 0.39$ & $\begin{array}{l}162.48 \\
\pm 0.33\end{array}$ & 98.29 & 106.68 & 104.87 \\
\hline Budyonny & 13 & $165.3 \pm 1.3$ & $157.3 \pm 0.92$ & $164.3 \pm 1.31$ & 99.39 & 105.08 & 104.45 \\
\hline Hanoverian & 17 & $166.2 \pm 0.78$ & $157.3 \pm 0.61$ & $164.0 \pm 0.83$ & 98.68 & 105.66 & 104.26 \\
\hline $\begin{array}{l}\text { Soviet Heavy } \\
\text { Draft }\end{array}$ & 54 & $166.8 \pm 0.51$ & $158.5 \pm 0.5$ & $167.0 \pm 0.5$ & 100.12 & 105.24 & 105.36 \\
\hline
\end{tabular}

The performance of heavy draft breeds correlates with the size and weight of the horse, which explains the greater massiveness and greater chest girth of heavy draft horses. In our study, Soviet Heavy Draft mares had not only a reliably larger chest girth compared to riding mares, but also a reliably larger chest width of $54.5 \mathrm{~cm}$, which is $12.5-16.5 \mathrm{~cm}$ more than that of riding mares. The chest depth of Soviet Heavy Draft mares is significantly greater than that of ridden mares. The relatively greater mass and more developed rib cage of the Soviet Heavy Draft mare is indicated by the larger index values, which characterize this body point compared to riding mares. The chest index shows the development of the rib cage in width and depth, as shown in Table 4, the more rounded in cross section chest cage of the Soviet Heavy Draft mares - the index was $64.19 \%$, and more flattened $-47.8 \%$ for the Budenny mares; Russian Saddle and Hanoverian mares occupy an intermediate position. More narrow and relatively flat chest was observed in Budenny mares, perhaps due to the fact that the horses of this breed are tested for performance in flat racing and such a structure creates less air resistance and provides advantage in the race.

Table 5 presents measurements and indices characterizing croup size in horses of different breeds. The highest croup length was observed in Soviet Heavy Draft mares, 61.2 $\mathrm{cm}$, which is reliably longer than in mares of other breeds, as evidenced by the higher croup to withers ratio, compared to riding mares, but the croup length to body length ratio was about the same as in riding mares. Soviet Heavy Draft horses while generally more massive 
and broad-bodied, had a reliably larger croup width at the hook bone $-66.7 \mathrm{~cm}$. In contrast to riding mares, heavy draft mares have a larger croup compared to the length - the ratio of these measurements is $108.99 \%$, while riding mares' croup was relatively narrower - the value of this ratio was $89.68-96.53 \%$.

Table 4. Measures and indices of chest development in mares of different breeds.

\begin{tabular}{|c|c|c|c|c|c|c|c|c|c|}
\hline \multirow[b]{2}{*}{ Breed } & \multirow[b]{2}{*}{$\frac{3}{d}$} & \multicolumn{3}{|c|}{$\begin{array}{c}\text { Body measurements } \\
(\mathrm{cm})\end{array}$} & \multicolumn{5}{|c|}{ Conformation indexes (\%) } \\
\hline & & 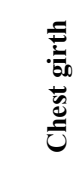 & 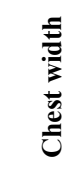 & 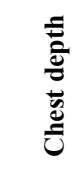 & 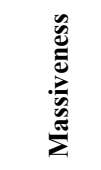 & 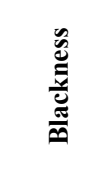 & 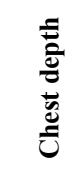 & 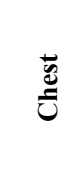 & 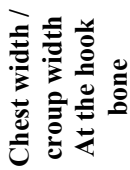 \\
\hline $\begin{array}{l}\text { Russian Saddle } \\
\text { Horse }\end{array}$ & 86 & $\begin{array}{l}194.9 \\
\pm 0.68 \\
\end{array}$ & $\begin{array}{l}41.9 \\
\pm 0.26 \\
\end{array}$ & $\begin{array}{l}80.8 \\
\pm 0.29 \\
\end{array}$ & 117.91 & 117.41 & 48.88 & 51.85 & 76.74 \\
\hline Budyonny & 13 & $\begin{array}{l}196.2 \\
\pm 2.0 \\
\end{array}$ & $\begin{array}{l}38.0 \\
\pm 0.74 \\
\end{array}$ & $\begin{array}{l}79.5 \\
\pm 0.89 \\
\end{array}$ & 118.69 & 117.41 & 48.09 & 47.80 & 71.97 \\
\hline Hanoverian & 17 & $\begin{array}{l}197.5 \\
\pm 2.41\end{array}$ & $\begin{array}{l}40.3 \\
\pm 0.67\end{array}$ & $\begin{array}{l}78.4 \\
\pm 1.03\end{array}$ & 118.83 & 116.72 & 47.17 & 51.40 & 78.56 \\
\hline $\begin{array}{l}\text { Soviet Heavy } \\
\text { Draft }\end{array}$ & 54 & $\begin{array}{l}224.2 \\
\pm 1.7 \\
\end{array}$ & $\begin{array}{l}54.5 \\
\pm 0.94 \\
\end{array}$ & $\begin{array}{l}84.9 \\
\pm 0.5 \\
\end{array}$ & 134.4 & 122.98 & 50.9 & 64.19 & 81.71 \\
\hline
\end{tabular}

Russian Saddle breed mares have more developed croup in comparison with mares of other sporting riding breeds, their croup was reliably longer and wider $(58$ and $54.6 \mathrm{~cm})$ than that of Budenny and reliably wider than that of Hanoverian mares. The relative croup size of Russian Saddler mares was also larger, at almost $35 \%$ of the body length, which suggests that Russian Saddle mares have a long croup. In addition, they have relatively wider croup than the Hanoverian breed mares. This should be considered a positive feature for the Russian Saddle breed, which specializes in dressage, a form of equestrian sport where the execution of most elements requires a significant transfer of the centre of gravity to the rear and load on the croup and hindquarters muscles.

Table 5. Measurements and indices of croup size for mares of different breeds.

\begin{tabular}{|l|c|c|c|c|c|c|}
\hline \multirow{2}{*}{ Breed } & & \multicolumn{2}{|c|}{ Qody measurements (cm) } & \multicolumn{2}{|c|}{ Conformation indexes (\%) } \\
\cline { 3 - 7 } & Q-ty & $\begin{array}{c}\text { Croup } \\
\text { length }\end{array}$ & $\begin{array}{c}\text { Croup width } \\
\text { at hook } \\
\text { bones }\end{array}$ & $\begin{array}{c}\text { Croup } \\
\text { length / } \\
\text { Height at } \\
\text { withers }\end{array}$ & $\begin{array}{c}\text { Croup length / } \\
\text { Body length }\end{array}$ & $\begin{array}{c}\text { Croup width } \\
\text { at hook bones } \\
\text { / Croup length }\end{array}$ \\
\hline $\begin{array}{l}\text { Russian Saddle } \\
\text { Horse }\end{array}$ & 86 & $58.0 \pm 0.23$ & $54.6 \pm 0.29$ & 35.09 & 34.94 & 94.14 \\
\hline Budyonny & 13 & $54.7 \pm 0.72$ & $52.8 \pm 0.62$ & 33.09 & 32.73 & 96.53 \\
\hline Hanoverian & 17 & $57.2 \pm 0.51$ & $51.3 \pm 0.77$ & 34.4 & 33.8 & 89.68 \\
\hline $\begin{array}{l}\text { Soviet Heavy } \\
\text { Draft }\end{array}$ & 54 & $61.2 \pm 0.62$ & $66.7 \pm 0.7$ & 36.8 & 33.57 & 108.99 \\
\hline
\end{tabular}

Structural features of the forelimbs of horses of different breeds are shown in Tables 6 and 7. Soviet Heavy Draft breed horses have shorter limbs, this is evidenced by the smaller leg height at the elbow compared with riding breed horses (significantly) and lower index of leg height. However, the extremities of the Soviet Heavy Draft mares are more bony, evidenced not only by the significantly larger metacarpus girth and the corresponding index (Table1), but also by significantly higher ratio of metacarpal girth to leg height at the elbow $-4-6 \%$ higher than in riding horses. The highest leg height at the elbow was found in Russian Saddle mares, but the difference between the averages was not significant. 
Table 6. Measurements of the articles of the front legs of the mares of different breeds $(\mathrm{cm})$.

\begin{tabular}{|l|c|c|c|c|c|c|c|}
\hline \multicolumn{1}{|c|}{ Breed } & Q-ty & $\begin{array}{c}\text { Shoulder } \\
\text { blade } \\
\text { length }\end{array}$ & $\begin{array}{c}\text { Shoulder } \\
\text { length }\end{array}$ & $\begin{array}{c}\text { Forearm } \\
\text { length }\end{array}$ & $\begin{array}{c}\text { Metacarpu } \\
\text { s length }\end{array}$ & $\begin{array}{c}\text { Pastern } \\
\text { length }\end{array}$ & $\begin{array}{c}\text { Leg length } \\
\text { at elbow }\end{array}$ \\
\hline $\begin{array}{l}\text { Russian Saddle } \\
\text { Horse }\end{array}$ & 86 & $56.5 \pm 0.29$ & $39.3 \pm 0.24$ & $48.7 \pm 0.19$ & $26.7 \pm 0.16$ & $13.2 \pm 0.12$ & 98.52 \\
\pm 0.19 \\
\hline Budyonny & 13 & $58.1 \pm 0.48$ & $45.3 \pm 0.52$ & $48.1 \pm 0.53$ & $24.7 \pm 0.21$ & $13.7 \pm 0.11$ & $97.9 \pm 0.38$ \\
\hline Hanoverian & 17 & $58.3 \pm 0.72$ & $41.3 \pm 0.59$ & $47.9 \pm 0.76$ & $23.9 \pm 0.41$ & $13.3 \pm 0.19$ & $96.5 \pm 0.23$ \\
\hline $\begin{array}{l}\text { Soviet Heavy } \\
\text { Draft }\end{array}$ & 54 & $62.7 \pm 0.64$ & $48.1 \pm 0.53$ & $45.3 \pm 0.45$ & $30.3 \pm 0.5$ & $10.9 \pm 0.24$ & $94.8 \pm 0.63$ \\
\hline
\end{tabular}

The longest shoulder blade and shoulder were observed in the Soviet Heavy Draft breed mares (significantly greater than in the riding horses), which is probably due not only to the larger size of the chest, but also to the fact that heavy draft horses have to develop more pulling power and need the large musculature in the shoulder blade and shoulder area.

The mares of the Russian Saddle breed had shorter shoulder blade and shoulder length, the shoulder blade length was reliably shorter than in the mares of other breeds, and the shoulder length was reliably shorter than in the mares of the Soviet Heavy Draft and Budenny breeds. Although the forelegs of dressage horses are not as loaded as those of show-jumping, triathlon or racing horses, a significantly shorter shoulder blade and shoulder length compared to other sports breeds is undesirable as it leads to reduced pushing force in the limbs.

Table 7. Indices characterizing the forelegs in mares of different breeds, $\%$.

\begin{tabular}{|c|c|c|c|c|c|c|c|c|c|c|c|}
\hline Breed & 完 & 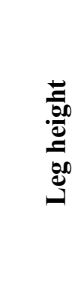 & 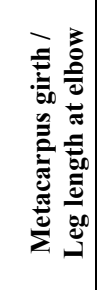 & 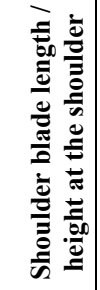 & 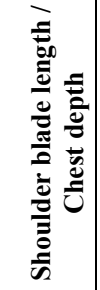 & 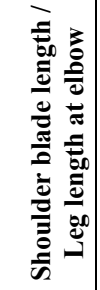 & 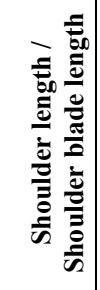 & 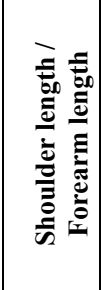 & 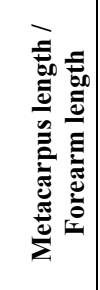 & 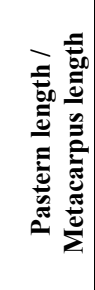 & 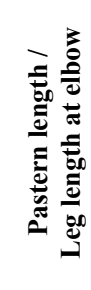 \\
\hline $\begin{array}{ll}\text { Russian } & \text { Saddle } \\
\text { Horse } & \\
\end{array}$ & 86 & 59.6 & 20.5 & 34.18 & 69.93 & 57.35 & 69.56 & 80.7 & 54.83 & 49.44 & 13.4 \\
\hline Budyonny & 13 & 59.23 & 21.45 & 35.15 & 73.08 & 59.35 & 77.97 & 94.18 & 51.35 & 55.47 & 13.99 \\
\hline Hanoverian & 17 & 58.06 & 22.49 & 35.08 & 74.36 & 60.41 & 70.84 & 86.22 & 49.9 & 55.6 & 13.78 \\
\hline $\begin{array}{ll}\text { Soviet } & \text { Heavy } \\
\text { Draft }\end{array}$ & 54 & 56.83 & 26.9 & 37.59 & 73.85 & 66.14 & 76.7 & 106.18 & 66.89 & 35.97 & 11.5 \\
\hline
\end{tabular}

Long forearm is considered a positive attribute for horses, as it provides a greater grasp of space when striding and trotting; this attribute is particularly important for sporting horses, whose quality of movement is assessed when competing [15]. Sporting horses have reliably longer forearms than that of Soviet Heavy Draft horses, and shorter metatarsals and pasterns. The indices showing the ratio of foreleg article lengths in horses also confirm that the forelimbs of heavy draft and riding horses have significant differences in the development of individual articles that are leveraged in the biomechanics of movement. 
Table 8. Measurements and indices of the hind legs in mares of different breeds.

\begin{tabular}{|c|c|c|c|c|c|c|c|c|}
\hline \multirow[b]{2}{*}{ Breed } & \multirow[b]{2}{*}{ did } & \multicolumn{4}{|c|}{$\begin{array}{c}\text { Body measurements } \\
(\mathrm{cm})\end{array}$} & \multicolumn{3}{|c|}{ Conformation indexes (\%) } \\
\hline & & 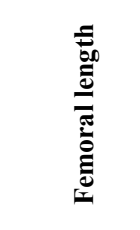 & 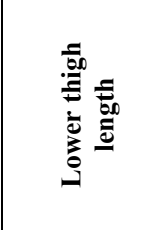 & 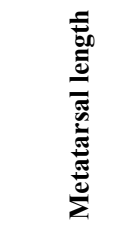 & 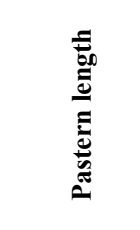 & 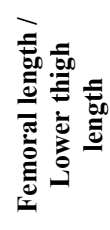 & 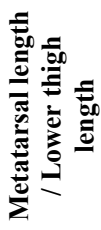 & 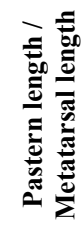 \\
\hline $\begin{array}{ll}\text { Russian } & \text { Saddle } \\
\text { Horse } & \\
\end{array}$ & 86 & $56.3 \pm 0.32$ & $56.2 \pm 0.25$ & $46.8 \pm 0.21$ & $13.8 \pm 0.13$ & 100.18 & 83.27 & 29.49 \\
\hline Budyonny & 13 & $58.0 \pm 0.27$ & $56.5 \pm 0.26$ & $46.3 \pm 0.32$ & $13.8 \pm 0.12$ & 102.65 & 81.95 & 29.81 \\
\hline Hanoverian & 17 & $57.6 \pm 0.69$ & $57.3 \pm 0.78$ & $44.1 \pm 0.52$ & $13.3 \pm 0.17$ & 100.52 & 76.96 & 30.16 \\
\hline $\begin{array}{l}\text { Soviet Heavy } \\
\text { Draft }\end{array}$ & 43 & $59.2 \pm 0.64$ & $53.3 \pm 0.71$ & $38.7 \pm 0.6$ & $11.6 \pm 0.2$ & 111.07 & 72.61 & 29.97 \\
\hline
\end{tabular}

When analyzing the structure of the hind legs of horses of different breeds, the same pattern as in the front legs is observed: a longer femur in Soviet Heavy Draft mares (the difference between the averages is only valid with Russian Saddle mares), shorter tibia and pastern. The ratios between the lengths of the hindquarters' articles confirm this trend; the exception is the ratio of pastern length to metatarsals length, which was close in value in mares of all breeds.

The results showed significant differences between the riding sporting breeds and heavy draft breeds. The riding sporting breeds were similar in most respects, but the Russian Saddle Horse had more differences compared to other riding breeds. Our research has shown that the selection of highly specialized types of horses leads to a distinct differentiation between breeds of horses in the exterior structure. The resulting digital data should be used for the development of standards and regulations in the breeding of horses for different uses. The significant differences between the breeds studied led to the following conclusions.

\section{Conclusions}

1. Soviet Heavy Draft mares were reliably superior to riding mares in most measurements and conformation indices, but inferior to them in terms of neck length.

2. Russian Saddle horses had significantly shorter head than the mares of other breeds, they were significantly lower in height at back, compared with other sporting breeds mares

3. Soviet Heavy Draft horses differed considerably from riding mares in forelimb structure, but had significantly longer shoulder blade, shoulder, metacarpus and hip lengths, but shorter leg heights at the elbow, forearm and pastern lengths.

4. The mares of the Russian Saddle breed had the shoulder blade and shoulder length reliably shorter than those of other breeds. They also had significantly smaller cannon metacarpus girth than Hanoverian breed horses.

5. In the structure of the hindquarters, there are fewer significant differences between Soviet Heavy Draft mares and riding mares: Soviet Heavy Draft mares have a longer femur, but shorter pastern. 


\section{References}

1. V. A. Demin, I. B. Tsyganyuk, Zootechnics, 1, 15-18 (2020)

2. V. A. Demin, I. B. Tsyganyuk, Agricultural Science, 11, 19-20 (2014)

3. V. A. Demin, E. V. Ryabova, Current Achievements and Current Issues in Horse Breeding, 73-79 (2019)

4. V. A. Demin, E. V. Ryabova, Zootechnics, 12, 16-17 (2014)

5. H. Ghezelsoflou, P. Hamidi, S. Gharahveysi, Journal of Equine Science, 29(4), 91-96

6. A. I. Gmel, T. Druml, R. von Niederhäusern, T. Leeb, M. Neuditschko, Genes, 10, 370 (2019)

7. AI. Gmel, T. Druml, K. Portele; R. von Niederhäusern, M. Neuditschko, PLoS ONE, 13(8)

8. M. Komosa, H. Frąckowiak, H. Purzyc, M. Wojnowska, A. Gramacki, J. Gramacki, Journal of Animal Science, 91, 1660-1668 (2013)

9. M. Komosa, H. Purzyc, Journal of Animal Science, 87, 7, 2245-2254 (2009)

10. B.M. Mongush, A. M. Zaitsev, M. M. Atroschenko, Yu. A. Yuldashbaev, V. A. Demin, Agricultural Science, 4, 40-43 (2020)

11. M. Mostafa, N. Senna, A. Abu-Seida, Y. Elemmawy, Journal of the Hellenic Veterinary Medical Society, 70(2), 1533-1540 (2019)

12. P. M. Parés-Casanova, A. Salamanca-Carreño, R. A. Crosby-Granados, J. A. BentezMolano, Animals, 10, 118 (2020)

13. V. A. Parfenov, Historical sketch of the formation and transformation of the Russian Saddle breed horses. State Studbook of Russian Saddle Breed Horses (2000)

14. J. Routh, C. Strang, S. Gilligan, and Dyson, Equine Vet Educ, 32, 183-192 (2020)

15. E. V. Ryabova, Science Alley, 5 (21) (2018)

16. G. J. Stefánsdóttir, A. Jansson, S. Ragnarsson, V. Gunnarsson, Comparative Exercise Physiology, 17(2), 151-160 (2020)

17. I. B. Tsyganyuk E. A. Yatsenko, TAA Reports, 347-351 (2019)

18. I. B. Tsyganyuk, Hippology and Veterinary, 2(20), 36-40 (2016) 